\title{
Desain Turunan Kalkon Baru sebagai Antikanker Payudara Berdasarkan Molecular Docking
}

\author{
Mutista Hafshah*1, Lilis Karlina ${ }^{2}$ \\ ${ }^{1}$ Kimia, Fakultas Sains dan Teknologi, UIN Walisongo Semarang \\ 2Kimia, Fakultas MIPA, Universitas Jenderal Soedirman \\ *E-mail: $\underline{\text { mutista.hafshah@walisongo.ac.id }}$
}

\begin{abstract}
Abstrak
Penelitian ini dilakukan untuk menentukan senyawa turunan kalkon yang berpotensi sebagai antikanker payudara berdasarkan Molecular Docking. Protein yang digunakan yaitu 17 $\beta$ hidroksisteroid dehydrogenase. Adapun ligan yang digunakan adalah 20 senyawa turunan kalkon yang dibandingkan dengan senyawa obat pembanding. Posisi pusat grid pada sisi aktif protein kanker payudara yang telah dilakukan pada penelitian sebelumnya yaitu pada leusin 149.X CB, serin 142.X OG, dan asparagine 152.X OD1. Software yang digunakan yaitu hyperchem, Gaussian03, Molden, Autodock Tools, Autodock4, dan chimera 1.5.3. Penelitian ini dilakukan dengan empat langkah yaitu pencarian kompleks protein-ligan 17 $\beta$-hidroksisteroid dehydrogenase dengan kode PDB 3HB4, optimasi struktur ligan dengan metode perhitungan AM1, molecular docking, dan pemilihan senyawa turunan kalkon sebagai antikanker payudara. Hasil docking turunan kalkon memiliki akivitas daya hambat terhapat protein $17 \beta$-hidroksisteroid dehydrogenase dengan nilai sebesar $4,41 \times 10^{-6} \mathrm{M}$ sampai $2,4783 \times 10^{-7} \mathrm{M}$. Hasil molecular docking didapatkan senyawa turunan kalkon sebagai antikanker payudara yaitu kalkon X memiliki tetapan inhibisi $2,4783 \times 10^{-7} \mathrm{M}$.
\end{abstract}

Kata Kunci : kalkon; kanker; molecular docking; inhibisi.

\begin{abstract}
This study was conducted to determine the potential of chalcone derived compounds as breast anticancer based on Molecular Docking approach. $17 \beta$ - hydroxysteroid dehydrogenase used as a protein and 20 ligand chalcone derivatives and comparator drug compounds. The position of the center of the grid on the active-site protein of breast cancer research has been done at leucine 149.X CB, serine 142.X OG, and asparagine 152.X OD1. Software used is hyperchem, Gaussian03, Molden, Autodock Tools, Autodock4, dand chimera 1.5.3 This study was carried out by four steps, namely the searching of protein-ligand complex 17 $\beta$-hidroksisteroid dehydrogenase with code PDB 3HB4, ligand structure optimization by using AM1 calculation method, molecular docking, and the selection of compounds chalcone derivative as breast anticancer. The results docking chalcone derivatives have inhibitory effect on protein activity of $17 \beta$-hydroxysteroid dehydrogenase has a value of $4.41 \times 2.4783 \times 10^{-6} \mathrm{M}$ to $10^{-7} \mathrm{M}$. The results Molecular Docking is derivates chalcone as breast anticancer called chalcone $X$ has an inhibition constant $2.4783 \times 10^{-7} \mathrm{M}$.
\end{abstract}

Keywords : chalcone; cancer; molecular docking; inhibition 


\section{Pendahuluan}

Kanker merupakan penyakit yang ditakuti oleh sebagian besar masyarakat saat ini. Terdapat 1 kasus kematian karena kanker setiap 11 menit, dan setiap 3 menit ada 1 penderita baru (Rasyidi, 2009). Kanker payudara menjadi salah satu jenis kanker yang menyebabkan kematian pada wanita.. Angka penderita kanker payudara di Indonesia menurut Departemen Kesehatan sebesar 876.665 orang. Rata-rata penderita kanker payudara di Indonesia adalah 10 dari 100 ribu perempuan, menjadikan penyakit ini berada di urutan kedua setelah kanker mulut rahim (Kusminarto, 2006).

Pengobatan kanker menggunakan kemoterapi sintetik dapat menimbulkan banyak efek samping negatif pada tubuh, diantaranya rentan terhadap infeksi, mudah lelah, mual, rambut rontok, pendarahan, dan sebagainya. Hal ini memicu para peneliti untuk mengeksplorasi kekayaan alam Indonesia khususnya tumbuhan yang memiliki aktivitas antikanker. Salah satu senyawa aktif dari tumbuhan yang berpotensi sebagai antikanker adalah kalkon.

Kalkon merupakan struktur umum yang banyak terdapat pada golongan flavonoid. Kalkon diketahui memiliki aktivitas biologis yang bervariasi, seperti sitotoksik, antioksidan (Ahmed et al., 2011), antikanker (Syam et al., 2012), antiinflamasi, antimikroba (kashyap et al., 2011), antialergi, dan antimalaria (Doan \& Tran, 2010). Penelitian aktvitas antikanker payudara terhadap MCF-7 yang telah dilakukan menunjukkan bahawa kalkon dengan gugus trimetoksi fenil yang memiliki efek sitotoksik dengan $\mathrm{IC}_{50}=0,21 \mathrm{nM}$, dan senyawa ini merupakan salah satu senyawa turunan kalkon yang telah disintesis (Saxena et al., 2007; Lawrence et al., 2003).

Kimia komputasi dapat melakukan uji in silico (dengan komputer) untuk menguji senyawa aktif dari suatu tumbuhan berpotensi memiliki aktivitas antikanker. Syarat utama untuk melakukan uji in silico (Molecular Docking/Penambatan Molekul) adalah adanya struktur kimia senyawa yang dimaksud (Purnomo, 2013). Beberapa kanker payudara rentan terhadap hormon seperti estrogen. Terjadinya ekspresi berlebihan suatu reseptor estrogen pada sel-sel tumor akan meningkatkan terjadinya proliferasi (fase sel saat mengalami pengulangan siklus sel tanpa hambatan) yang berlebihan (Yager, 2006; Jordan, 2003). Penemuan reseptor estrogen, selain bisa digunakan sebagai prediksi dan penanda prognostik (karakteristik yang memberikan indikasi kemungkinan perkembangan penyakit), bisa juga sebagai target yang efisien untuk pengobatan kanker payudara hormone dependent dengan antiestrogen. Salah satu penyebab petumbuhan sel kanker juga adanya enzim $17 \beta$ hidroksisteroid dehidrogenase yang disebut sebagai reseptor. Enzim $17 \beta$-hidroksisteroid dehidrogenase dapat juga berfungsi sebagai target yang efisien untuk pengobatan kanker payudara. Penelitian yang telah dilakukan yaitu penentuan pusat grid pada protein $17 \beta-$ hidroksisteroid dehidrogenase. Persiapan untuk penelitian lanjutan mengunakan pusat grid yang sudah didapat yaitu pada Leusin 149.X CB, Asparagin 152.X OD1, dan Serin 142.X OG (Nurjanah, 2014).

Berdasarkan uraian mengenai kimia komputasi, untuk mendapatkan senyawa yang diperkirakan memiliki aktivitas antikanker payudara maka dilakukan kajian in silico terhadap turunan kalkon dan desain turunan kalkon baru menggunakan reseptor $17 \beta$ hidroksisteroid dehidrogenase melalui docking pada pusat grid yang telah diketahui. Diharapkan dari uji in silico ini didapatkan senyawa yang lebih berpotensi sebagai antikanker payudara berdasarkan hasil docking terhadap reseptor 17ß-hidroksisteroid dehidrogenase dan kemudian hasil docking ini dapat disintesis dan dilakukan uji aktivitas antikanker.

\section{8}

Copyright @ 2019 WJC | ISSN 2621-5985 (online) | ISSN 2549-385X (print)

Volume 2, Nomor 2, 2019 


\section{Metode Penelitian}

\section{Alat dan Bahan}

Penelitian ini merupakan penelitian teoritik yang menggunakan koordinat struktur kompleks protein kanker payudara dengan senyawa obat yang diunduh dari Protein Data Bank (PDB) dengan kode 3HB4. Senyawa obat pada kompleks protein kanker payudara selanjutnya disebut ligan. Penelitian ini menggunakan 17 desain turunan kalkon (Pratoko, 2013) dan 3 desain turunan kalkon baru karya peneliti serta senyawa obat lainya.

Alat yang digunakan pada penelitian terdiri dari perangkat keras komputer dengan spesifikasi prosesor intel ${ }^{\circledR}$ Core (TM) i7-2600 CPU @3.40GHz dan RAM 4 GB. Perangkat lunak yang digunakan untuk perhitungan kimia komputasi adalah Hyperchem untuk menggambar struktur ligan, Gaussian03 untuk mengoptimasi struktur ligan, Molden untuk mengubah koordinat xyz ke koordinat format pdb. Kemudian Autodock Tools untuk pemilihan pusat grid pada struktur protein, Autodock 4.0 untuk melakukan docking molekul dan USCF Chimera untuk memvisualkan dan menganalisis hasil docking molekul senyawa obat dengan protein kanker payudara.

\section{Prosedur Kerja}

Molecular docking yang dilakukan pada penelitian ini adalah menggunakan program Autodock Tools. Adapaun tahapan prosesnya yaitu pencarian kompleks protein-ligan kanker payudara, optimasi struktur ligan, dan docking molekul.

Pencarian kompleks protein-ligan kanker payudara pada file PDB (protein data base) melalui situs www.rscb.org,Kompleks protein-ligan yang digunakan adalah $17 \beta$ hidroksisteroid dehidrogenase yang berkode 3HB4, dengan ligan (3-\{[(9beta,14beta, 16alpha,17alpha)-3,17-dihidroksiestra-1,3,5 (10)-trien-16yl]metil\} benzamid) (Nurjanah, 2014).

Optimasi struktur ligan; ligan yang digunakan merupakan 20 desain struktur turunan kalkon baru dan 3 senyawa obat pembanding dari turunan kalkon (senyawa A, doxorubicin, dan ligan $17 \beta-$ DHB) yang digambar menggunakan software hyperchem untuk mendapat koordinat $\mathrm{x}, \mathrm{y}$, dan $\mathrm{z}$ dengan metode semiempiris AM1. Data koordinat semua turunan kalkon yang didapat dari perhitungan hyperchem dipindahkan ke dalam software Gaussian03 dan dioptimasi menggunakan basis set 6-31G*.

Molecular docking; menyiapkan ligan dan protein target yang akan didocking kemudian penentuan pusat grid dan parameter docking molekul. Pusat grid yang digunakan pada docking molekul turunan kalkon sebagai antikanker pada penelitian ini adalah serin 142.X OG, leusin $149 \mathrm{X} \mathrm{CB}$, dan asparagin $152 \mathrm{X}$ ODI (Nurjanah, 2014).

\section{Hasil Penelitian dan Pembahasan}

Docking adalah metode untuk memprediksi posisi yang terbaik dari suatu molekul ketika terikat satu sama lain untuk membentuk kompleks yang stabil. Informasi tentang orientasi ini dapat digunakan untuk memprediksi kekuatan hubungan atau afinitas antara dua molekul yang digunakan. Tujuan dari docking adalah untuk mencapai konformasi protein dan ligan yang optimal sehingga energi bebas dari sistem secara keseluruhan diminimalkan. Docking membantu dalam mempelajari interaksi obat/ligan dengan reseptor/protein melalui identifikasi situs aktif yang cocok pada protein, mendapatkan geometri terbaik dari kompleks ligan-reseptor, dan menghitung energi interaksi dari ligan yang berbeda untuk merancang ligan yang lebih efektif (Arry, 2012).

Docking molekul dilakukan pada 23 struktur senyawa, 20 senyawa turunan senyawa kalkon, dan 3 yang lainnya berupa senyawa pembanding. Senyawa A adalah senyawa induk kalkon hasil sintesis, doxorubicin merupakan antibiotik golongan antrasiklin yang sudah banyak digunakan untuk terapi berbagai macam jenis kanker seperti leukemia, kanker payudara, kanker tulang, dan ovarium (Childs et al., 2002). 
M. Hafshah, L. Karlina

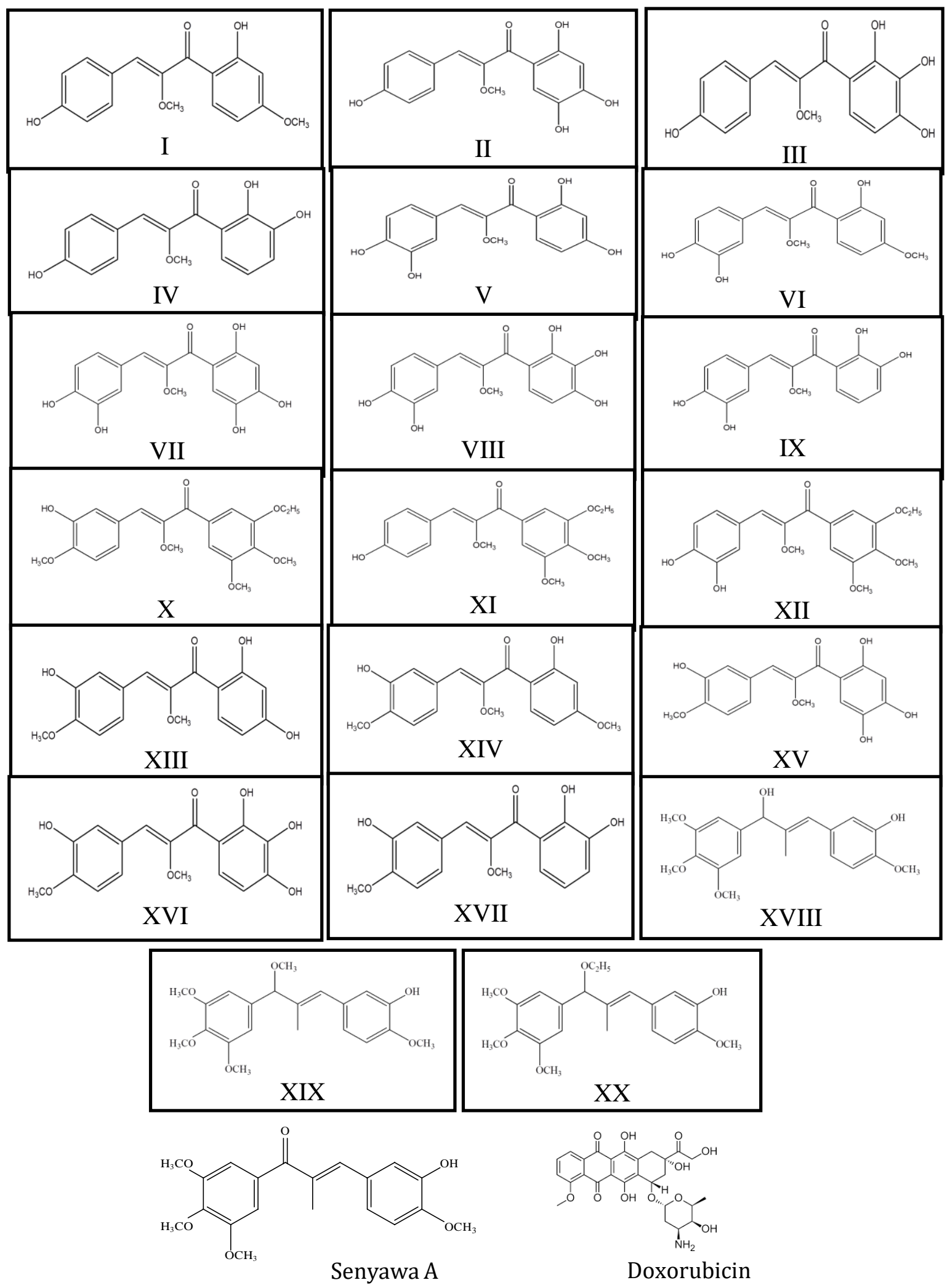

Gambar 1. Desain 17 (I-XVII) struktur senyawa turunan kalkon (Pratoko et al., 2013) dan 3 (XVIII$\mathrm{XX)}$ desain turunan kalkon baru karya peneliti, Struktur obat senyawa A, dan doxorubicin.

60

Copyright @ 2019 WJC | ISSN 2621-5985 (online) | ISSN 2549-385X (print)

Volume 2, Nomor 2, 2019 
Desain Turunan Kalkon...

Tabel 1. Hasil docking pada pusat grid serin 142.X OG

\begin{tabular}{llll}
\hline No & \multicolumn{1}{c}{ Senyawa } & $\begin{array}{c}\text { Binding } \\
\text { Energy } \\
\text { (kkal/mol) }\end{array}$ & $\begin{array}{c}\text { Inhibition } \\
\text { Constant }(\mathrm{M})\end{array}$ \\
\cline { 3 - 4 } 1 & Kalkon I & $-8,26$ & $8,8097 \times 10^{-7}$ \\
\hline 2 & Kalkon II & $-7,52$ & $3,05 \times 10^{-6}$ \\
\hline 3 & Kalkon III & $-7,50$ & $3,15 \times 10^{-6}$ \\
\hline 4 & Kalkon IV & $-7,83$ & $1,83 \times 10^{-6}$ \\
\hline 5 & Kalkon V & $-7,82$ & $1,82 \times 10^{-6}$ \\
\hline 6 & Kalkon VI & $-7,90$ & $1,62 \times 10^{-6}$ \\
\hline 7 & Kalkon VII & $-7,64$ & $2,49 \times 10^{-6}$ \\
\hline 8 & Kalkon VIII & $-7,74$ & $2,12 \times 10^{-6}$ \\
\hline 9 & Kalkon IX & $-7,99$ & $1,39 \times 10^{-6}$ \\
\hline $\mathbf{1 0}$ & Kalkon X & $-\mathbf{9 , 0 0}$ & $\mathbf{2 , 5 4 0 8 \times \mathbf { 1 0 } ^ { - 7 }}$ \\
\hline 11 & Kalkol XI & $-8,50$ & $5,9148 \times 10^{-7}$ \\
\hline 12 & Kalkon XII & $-8,54$ & $5,4992 \times 10^{-7}$ \\
\hline 13 & Kalkon XIII & $-7,94$ & $1,51 \times 10^{-6}$ \\
\hline 14 & Kalkon XIV & $-8,45$ & $6,43 \times 10^{-7}$ \\
\hline 15 & Kalkon XV & $-7,80$ & $1,92 \times 10^{-6}$ \\
\hline 16 & Kalkon XVI & $-7,61$ & $2,63 \times 10^{-6}$ \\
\hline 17 & Kalkon XVII & $-8,66$ & $4,5207 \times 10^{-7}$ \\
\hline 18 & Kalkon XVIII & $-8,67$ & $3,989 \times 10^{-7}$ \\
\hline 19 & Kalkon XIX & $-7,98$ & $1,42 \times 10^{-6}$ \\
\hline 20 & Kalkon XX & $-8,37$ & $7,2949 \times 10^{-7}$ \\
\hline 21 & Senyawa A & $-9,09$ & $2,1741 \times 10^{-7}$ \\
\hline 22 & ligan17 $\beta$ DHB & $-12,93$ & $3,3288 \times 10^{-7}$ \\
\hline 23 & doxorubicin & $-10,06$ & $4,195 \times 10^{-8}$ \\
\hline & & & \\
\hline
\end{tabular}

Tabel 2. Hasil docking pada pusat grid leusin $149 \times \mathrm{XB}$

\begin{tabular}{llll}
\hline No & Senyawa & $\begin{array}{c}\text { Binding } \\
\text { Energy } \\
(\mathrm{kkal} / \mathrm{mol})\end{array}$ & $\begin{array}{c}\text { Inhibition } \\
\text { Constant }(\mathrm{M})\end{array}$ \\
\cline { 3 - 4 } 1 & Kalkon I & $-8,11$ & $1,14 \times 10^{-6}$ \\
\hline 2 & Kalkon II & $-7,42$ & $3,63 \times 10^{-6}$ \\
\hline 3 & Kalkon III & $-7,31$ & $4,41 \times 10^{-6}$ \\
\hline 4 & Kalkon IV & $-7,90$ & $1,61 \times 10^{-6}$ \\
\hline 5 & Kalkon V & $-7,85$ & $1,77 \times 10^{-6}$ \\
\hline 6 & Kalkon VI & $-8,31$ & $8,0833 \times 10^{-7}$ \\
\hline 7 & Kalkon VII & $-7,69$ & $2,31 \times 10^{-6}$ \\
\hline 8 & Kalkon VIII & $-8,10$ & $1,16 \times 10^{-6}$ \\
\hline 9 & Kalkon IX & $-7,63$ & $2,55 \times 10^{-6}$ \\
\hline $\mathbf{1 0}$ & Kalkon X & $\mathbf{- 8 , 8 3}$ & $\mathbf{3 , 3 8 6 9 \times 1 0 ^ { - 7 }}$ \\
\hline 11 & Kalkol XI & $-8,50$ & $5,8483 \times 10^{-7}$ \\
\hline 12 & Kalkon XII & $-8,35$ & $7,5652 \times 10^{-7}$ \\
\hline 13 & Kalkon XIII & $-8,10$ & $1,51 \times 10^{-6}$ \\
\hline 14 & Kalkon XIV & $-7,82$ & $1,84 \times 10^{-7}$ \\
\hline 15 & Kalkon XV & $-7,81$ & $1,88 \times 10^{-6}$ \\
\hline 16 & Kalkon XVI & $-8,36$ & $7,4279 \times 10^{-6}$ \\
\hline 17 & Kalkon XVII & $-8,41$ & $6,8435 \times 10^{-7}$ \\
\hline
\end{tabular}

\begin{tabular}{|c|c|c|c|}
\hline No & Senyawa & $\begin{array}{c}\text { Binding } \\
\text { Energy } \\
(\mathrm{kkal} / \mathrm{mol})\end{array}$ & $\begin{array}{c}\text { Inhibition } \\
\text { Constant }(\mathrm{M})\end{array}$ \\
\hline 18 & Kalkon XVIII & $-8,49$ & $6,0043 \times 10^{-7}$ \\
\hline 19 & Kalkon XIX & $-7,91$ & $1,59 \times 10^{-6}$ \\
\hline 20 & Kalkon XX & $-8,23$ & $9,2828 \times 10^{-7}$ \\
\hline 21 & Senyawa A & $-8,96$ & $2,7263 \times 10^{-7}$ \\
\hline 22 & ligan $17 \beta \mathrm{DHB}$ & $-13,02$ & $1,302 \times 10^{-8}$ \\
\hline 23 & doxorubicin & $-10,38$ & $2,459 \times 10^{-8}$ \\
\hline
\end{tabular}

Tabel 3. Hasil docking pada pusat grid asparagin 152 X ODI

\begin{tabular}{llll}
\hline No & \multicolumn{1}{c}{ Senyawa } & $\begin{array}{c}\text { Binding } \\
\text { Energy } \\
\text { (kkal/mol) }\end{array}$ & $\begin{array}{c}\text { Inhibition } \\
\text { Constant }(\mathrm{M})\end{array}$ \\
\cline { 3 - 4 } 1 & Kalkon I & $-8,22$ & $9,5001 \times 10^{-7}$ \\
\hline 2 & Kalkon II & $-7,52$ & $3,05 \times 10^{-6}$ \\
\hline 3 & Kalkon III & $-7,39$ & $3,86 \times 10^{-6}$ \\
\hline 4 & Kalkon IV & $-7,85$ & $1,77 \times 10^{-6}$ \\
\hline 5 & Kalkon V & $-8,04$ & $1,28 \times 10^{-6}$ \\
\hline 6 & Kalkon VI & $-8,23$ & $1,62 \times 10^{-6}$ \\
\hline 7 & Kalkon VII & $-7,60$ & $2,67 \times 10^{-6}$ \\
\hline 8 & Kalkon VIII & $-8,14$ & $1,09 \times 10^{-6}$ \\
\hline 9 & Kalkon IX & $-7,99$ & $1,40 \times 10^{-6}$ \\
\hline $\mathbf{1 0}$ & Kalkon X & $-\mathbf{9 , 0 1}$ & $\mathbf{2 , 4 7 8 3 \times 1 0 ^ { - 7 }}$ \\
\hline 11 & Kalkol XI & $-8,49$ & $5,9432 \times 10^{-7}$ \\
\hline 12 & Kalkon XII & $-8,72$ & $4,0619 \times 10^{-7}$ \\
\hline 13 & Kalkon XIII & $-7,92$ & $1,57 \times 10^{-6}$ \\
\hline 14 & Kalkon XIV & $-8,43$ & $6,5729 \times 10^{-7}$ \\
\hline 15 & Kalkon XV & $-8,13$ & $1,10 \times 10^{-6}$ \\
\hline 16 & Kalkon XVI & $-8,44$ & $6,4553 \times 10^{-6}$ \\
\hline 17 & Kalkon XVII & $-8,62$ & $4,7805 \times 10^{-7}$ \\
\hline 18 & Kalkon XVIII & $-8,65$ & $4,5816 \times 10^{-7}$ \\
\hline 19 & Kalkon XIX & $-7,81$ & $1,88 \times 10^{-6}$ \\
\hline 20 & Kalkon XX & $-8,43$ & $6,6645 \times 10^{-7}$ \\
\hline 21 & Senyawa A & $-9,03$ & $2,407 \times 10^{-7}$ \\
\hline 22 & ligan17 $\beta$ DHB & $-13,40$ & $1,5139 \times 10^{-7}$ \\
\hline 23 & doxorubicin & $-11,61$ & $3,07 \times 10^{-9}$ \\
\hline & & & \\
\hline
\end{tabular}

Ket:

$$
\begin{aligned}
& \text { Nilai IC Tertinggi } \\
& \text { NIlai IC Terendah } \\
& \text { Senyawa Pembanding }
\end{aligned}
$$

Hasil docking antara ligan dengan protein pada pusat grid serin 142.X OG, leusin 149 X CB dan asparagin $152 \mathrm{X}$ ODI menunjukkan bahwa kalkon X merupakan senyawa kalkon hasil desain terbaru yang memiliki potensi tertinggi sebagai antikanker payudara dibandingkan senyawa kalkon hasil desain baru yang lain . 
M. Hafshah, L. Karlina

Gambar 2, 3, dan 4 menunjukkan interaksi (docking molekul) antara pusat grid serin 142.X OG, leusin $149 \mathrm{X} \mathrm{CB}$, dan asparagin $152 \mathrm{X}$ ODI dengan senyawa kalkon $\mathrm{X}$. Kalkon $\mathrm{X}$ memiliki potensi aktivitas antikanker terbaik karena kalkon X memiliki nilai inhibition constant yang paling rendah dan binding energy yang kecil (semakin negatif). Adapun nilai binding energy senyawa kalkon $\mathrm{X}$ pada masing-masing pusat grid berturut-turut adalah -9,00; -8,83; dan 9,01. Binding energy merupakan afinitas dari ligan yang berikatan dengan protein membentuk kompleks protein-ligan dalam keadaan kesetimbangan. Kestabilan kompleks yang terbentuk antara protein dengan ligan dapat memberikan gambaran mengenai afinitas antara ligan dengan protein. Afinitas proteinligan dipengaruhi oleh interaksi intermolekul non kovalen antara dua molekul seperti ikatan hidrogen, interaksi elektrostatik, hidrofobik, dan gaya Van der Waals.

\section{Nilai Inhibition}

constant

menunjukkan konsentrasi senyawa terendah yang dapat memberikan aktivitas biologis tertentu. Senyawa Kalkon X menunjukkan nilai IC yang rendah jika dibandingkan dengan senyawa turunan kalkon hasil desain yang lain. Adapun nilai IC dari senyawa Kalkon X pada pusat grid serin 142 X OG, leusin 149 X CB dan asparagin $152 \mathrm{X}$ ODI berturut-turut adalah $2,5408 \times 10^{-7} ; 3,3869 \times 10^{-7} ;$ dan $2,4783 \times 10^{-}$ 7. Hal tersebut menunjukkan bahwa pada konsenstrasi-konsentrasi tersebut, senyawa Kalkon X sudah dapat menghambat pertumbuhan sel kanker payudara. Semakin kecil inhibition constant, semakin kuat penempelan ligan atau semakin tinggi afinitas ligan dengan protein. Semakin banyak interaksi dari ligan dengan sisi aktif protein maka fungsi ligan sebagai inhibitor semakin baik. Meskipun demikian, data analisis docking senyawa turunan kalkon baru masih memiliki aktivitas yang lebih rendah dibandingkan dengan senyawa pembanding. Doxorubicin memiliki nilai IC paling rendah ketika berinteraksi dengan grid asparagine $152 \mathrm{X}$ ODI yaitu mencapai 3,07 × 10-9.

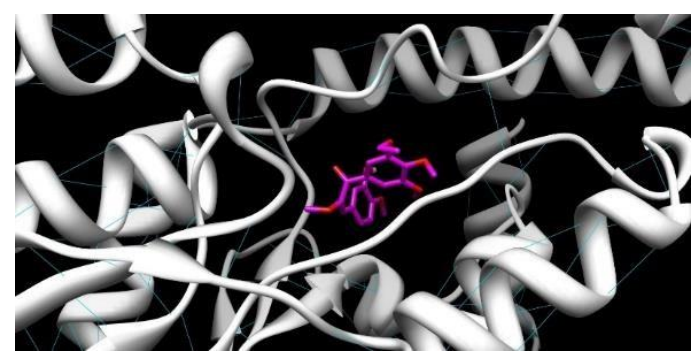

Gambar 1. Hasil docking molekul pada pusat grid Serin 142 X OG dengan Kalkon X

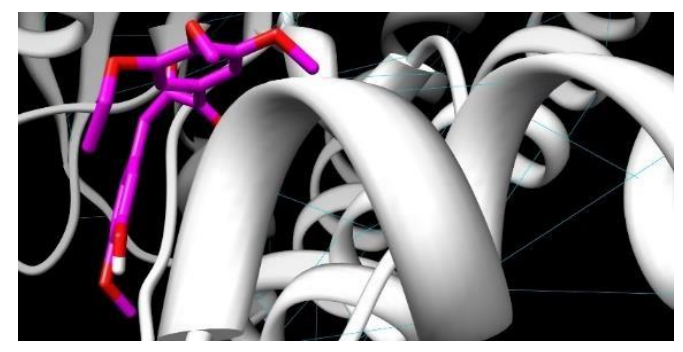

Gambar 1. Hasil docking molekul pada pusat grid leusin 149 X CB dengan Kalkon X

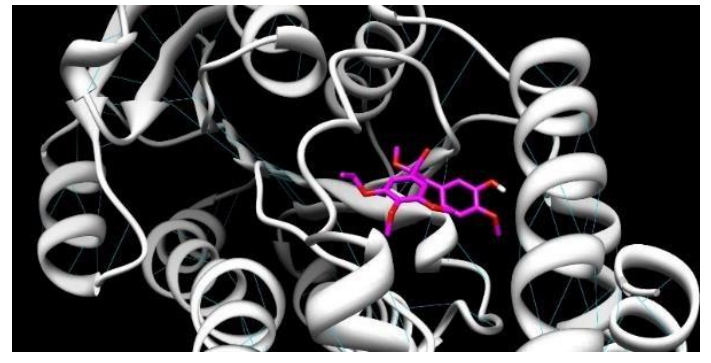

Gambar 1. Hasil docking molekul pada pusat grid asparagin 152 X ODI dengan Kalkon X

\section{Simpulan}

Aktivitas daya hambat turunan kalkon terhadap protein $17 \beta$-Hidroksisteroid Dehidrogenase berdasarkan molecular docking memiliki nilai sebesar 4,41 $\times 10^{-6} \mathrm{M}$ sampai $2,4783 \times 10^{-7} \mathrm{M}$. Desan turunan kalkon sebagai antikanker payudara yang terbaik yaitu kalkon $\mathrm{X}$ dibanding turunan kalkon lainnya.

\section{Ucapan Terima Kasih}

Terimakasih kepada Bapak Dr. Ponco Iswanto dan Ibu Dra. Eva Vaulina, Y. D., M.Si yang telah membimbing dan memfasilitasi riset ini di 
laboratorium kimia komputasi Universitas Jenderal Soedirman Purwokerto.

\section{Daftar Pustaka}

Ahmed, R.M., Sastry, G.V., Bano, N., Ravichandra, S., and Raghavendra, M. (2011). Synthesis and Cytotoxic, Antioxidant Activities of New Chalcone Derivatives. Rasayan Journal Chemistry. 4(2): 289294.

Arry, Y. (2012). Penambatan Molekular: Praktek dan Aplikasi Virtual Screening.

Child, A. C., Phaneuf, S. L., Dirks, A. J., Phillips, T., and Leeuwenburgh. (2002). Doxorubicin Treatment in Vvo Causes Cytochrome Release and Cardiomyocyte Apoptosis, As Well As Increased Mitochondrial Efficiency, Superoxide Dismutase Activity, and Bcl-2:Bax Ratio, Cancer Research, 62:4592-4598.

Doan, T.N., \& Tran, D.T. (2011). Synthesis, Antioxidant and Antimicrobial Activities of a Novel Series of Chalcones, Pyrazolic Chalcones, and Allylic Chalcones. Scientific Research. 2: 282-288.

Kashyap, S.J., Garg, V.K., Dudhe, R., Sharma, P.K \& Kumar, N. (2011). Synthesis and Invitro Antioxidant Activity of Substituted Chalcone Derivatives. International Journal of Drug Formulation and Research. 4 (2): 324336.

Kusminarto, 2006. Deteksi Sangat Dini Kanker Payudara: Jawaban untuk Menghindar. [online]

Http://www.depkes.go.id/index.php. Diakses pada tanggal 31 Desember 2014.
Lawrence, N. J., Rennison D., McGown A. T., Hadfield J. A. (2003). The total synthesis of an aurone isolated from Uvaria hamiltonii: aurones and flavones as anticancer agents. Bioorg Med Chem Let. 13: 3759-3763.

Nurjanah, F., (2014). Validasi Pusat Grid Docking Molekul pada Sisi Aktif Protein Kanker Payudara. Skripsi. Purwokerto: Universitas Jenderal Soedirman.

Pratoko, D. (2013). Molecular Docking Turunan Kalkon Terhadap Reseptor Estrogen $\beta$ (ER- $\beta$ ) Sebagai Antikanker Payudara. Jember:Universitas Jember.

Purnomo, H. (2013). Asam Amino, Buku Ajar Kimia Universitas Wiraraja Sumenep. Jawa Timur: FMIPA Universitas Wiraraja Sumenep.

Rasyidi. (2009). Epidemiologi kanker serviks. Indonesian Journal of Cancer. 3:103-8.

Saxena, H. O., Faridi U., Kumar J. K., Luqman S., Darokar M. P., Shanker K., Chanotiya C. S., Gupta M. M., Negi A. S. (2007). Synthesis of Chalcone Derivatives on Steroidal Framework and Their Anticancer Activities. Steroids. 72: 892900.

Syam, S., Abdelwahab, S.I., Al-Mamary, M.A., and Mohan, S. (2012). Synthesis of Chalcones with Anticancer Activities. Molecules. 17: 6179-6195.

Yager, J. (2006). Estrogen Carcinogenesis in Breast Cancer. N Engl J Med. 354: 270 282. 